\title{
CHEMICAL CONTROL OPTIONS FOR THE DICAMBA RESISTANT BIOTYPE OF FATHEN (CHENOPODIUM ALBUM)
}

\author{
A. RAHMAN, T.K. JAMES and M.R. TROLOVE \\ AgResearch, Ruakura Research Centre, Private Bag 3123, \\ Hamilton 3240, New Zealand
}

Corresponding author: anis.rahman@agresearch.co.nz.

\begin{abstract}
Three field trials were conducted over two growing seasons to evaluate the efficacy of potential selective post-emergence herbicides against dicamba resistant fathen (Chenopodium album). Results confirmed the presence of the biotype, which tolerated dicamba up to $2400 \mathrm{~g} / \mathrm{ha}$, eight times the recommended field rate. Post-emergence applications of bromoxynil, pyridate, nicosulfuron and mesotrione all showed equally good efficacy on both susceptible and resistant biotypes. Flumetsulam provided good control in one of the three trials. Nicosulfuron and mesotrione provided long term residual control in all trials, with nicosulfuron also being more effective on grass weeds. The $2400 \mathrm{~g} / \mathrm{ha}$ rate of dicamba severely damaged the maize crop, resulting in increased weed cover and reduced grain yield. Numbers of viable fathen seeds in the soil at the end of the growing season remained similar to those recorded before planting, except in plots that provided good control of fathen, where numbers had dropped considerably. Keywords: herbicide resistance, fathen, Chenopodium album, dicamba, maize, chemical control.
\end{abstract}

\section{INTRODUCTION}

The continuous use of residual herbicides in arable cropping led to the first case of herbicide resistance in New Zealand in maize fields and, like most countries, it was resistance to atrazine by fathen (Chenopodium album) (Rahman 1982). The steady spread of this biotype has forced growers to use an additional post-emergence herbicide to achieve control.

Results of field trials showed no difference between susceptible and atrazine resistant biotypes of fathen in their tolerance to post-emergence treatments with 2,4-D, dicamba, bentazone and bromophenoxim (Rahman et al. 1983). More recent field studies also showed good efficacy of pyridate, bromoxynil and nicosulfuron on both susceptible and resistant biotypes in maize crops (Rahman et al. 2001b). Dicamba has been the most widely used chemical of these post-emergent herbicides due to its efficacy, the wide spectrum of weeds controlled and its relatively low cost. However, inadequate control of the atrazine resistant biotype in some maize fields in recent years, and our investigations, have now confirmed that resistance has also developed to the herbicide dicamba (James et al. 2005). The need to effectively control and limit the spread of this dicamba resistant biotype, as well as to provide alternative chemical options to prevent further instances of resistance, led to these field trials to investigate and compare the efficacy of other selective herbicides currently available to maize growers.

\section{MATERIALS AND METHODS}

Three field trials were conducted in Waikato on maize fields where fathen was a problem in the previous season. The two sites used had been cropped with maize for several years and treated each year with atrazine in combination with a grass herbicide. 
Trial 1 was on a site where dicamba had also been used occasionally on maize crops in past years and had an infestation of suspected dicamba resistant biotype. Trials 2 and 3 were carried out in consecutive growing seasons on a site that had been treated with dicamba each year for several years and had a heavy infestation of fathen, a proportion of which was confirmed to be the dicamba resistant biotype (James et al. 2005).

Trial 1 was on a Te Puninga loamy sand soil with an organic C content of $7.2 \%$ and a $\mathrm{pH}$ of 5.8, while the site for Trials 2 and 3 was a Waihou silt loam soil with an organic $\mathrm{C}$ of $6.6 \%$ and a pH of 6.2. Plot size in all trials was $3 \mathrm{~m} \times 10 \mathrm{~m}$ and maize cv. Pioneer 36B08 was planted in rows $75 \mathrm{~cm}$ apart on 29 October 2005, 4 November 2005 and 1 November 2006 in Trials 1, 2 and 3, respectively. Treatments were arranged in a randomised block design with four replicates.

A pre-emergence treatment of metolachlor (Dual Gold) + atrazine (Gesaprim) at $1.92+1.0 \mathrm{~kg}$ ai/ha was applied to Trial 1 on 2 November 2005 and to Trial 2 on 4 November 2005. The post-emergence treatments were applied on 8 December 2005 , 24 December 2005 and 12 December 2006 in Trials 1, 2 and 3 respectively. The maize crop at this time was at 5-6 leaf stage (average height $30 \mathrm{~cm}$ ) in Trials 1 and 3 and 8-9 leaf stage (average height $55 \mathrm{~cm}$ ) in Trial 2 . Herbicides pyridate (Tough) and flumetsulam (Preside) were applied with the adjuvant Uptake $0.5 \% \mathrm{v} / \mathrm{v}$, nicosulfuron (Amaze) with Activator $0.5 \% \mathrm{v} / \mathrm{v}$ and mesotrione (Callisto) with Synoil 0.5\% v/v. Bromoxynil (Emblem) and dicamba (Crop Care Dicamba) were used without any adjuvant. All the herbicide treatments were applied with a $\mathrm{CO}_{2}$ powered back pack sprayer with a $3 \mathrm{~m}$ boom fitted with four Teejet 11003 nozzles to deliver 200 litres/ha at $200 \mathrm{kPa}$.

Visual assessments on percent control of fathen based on plant damage and ground cover, relative to untreated plots, were made in all trials at various intervals after spraying of treatments. In Trial 3 these assessments were recorded also for other weeds present on 14 February 2007, about 9 weeks after treatment. Additionally, data on number of plants and biomass of broadleaf and grass weeds were collected on the same day by counting and then harvesting duplicate $0.1 \mathrm{~m}^{2}$ quadrats from each plot. While counting the fathen plants in untreated plots, an attempt was made to differentiate them into susceptible and resistant biotypes based on morphological differences (James et al. 2005).

Maize grain yield was also determined in Trial 3 by harvesting cobs from $5 \mathrm{~m}$ strips in the central two rows of each plot on 1 May 2007. The shelled grain was weighed and a subsample collected for moisture determination. Grain moisture was determined by drying a $200 \mathrm{~g}$ sample at $105^{\circ} \mathrm{C}$ for $24 \mathrm{~h}$ and grain yields were adjusted to $14 \%$ moisture content.

In order to assess the influence of herbicide treatments on the soil seedbank of fathen, 100 soil cores $(25 \mathrm{~mm}$ diam $\times 100 \mathrm{~mm}$ deep) were collected from the trial area by dividing it into five zones $(6 \mathrm{~m} \times 40 \mathrm{~m}$ strips) on 21 September 2006, after the last spring cultivation. Soil samples were collected again from the untreated, mesotrione and all dicamba treatments on 2 May 2007, the day after the crop was harvested. All samples were air dried and then numbers of viable fathen seed were counted by both seed enumeration and seedling germination methods (Rahman et al. 2001a).

All the data were subjected to ANOVA to separate treatment means. The arithmetic means and least significant differences (LSD) are presented in the tables. Data on dry matter production were $\log$ transformed $[\log (x+1)]$ before analysis and the differences between means were identified with the Duncan's Multiple Range Test.

\section{RESULTS AND DISCUSSION}

In Trial 1 all herbicide treatments except flumetsulam provided excellent control of fathen within a month after application and this lasted well into the growing season (Table 1). As all dicamba treatments, including the lowest rate of $300 \mathrm{~g} / \mathrm{ha}$ gave nearly complete control, it can be concluded that most fathen plants on this site were the susceptible biotype. In Trial 2, however, dicamba rates even up to eight times the recommended rate $(2400 \mathrm{~g} / \mathrm{ha})$ did not provide complete control of fathen at any stage (Table 1), suggesting that this site had a substantial proportion of dicamba resistant 
fathen. The initial high efficacy of dicamba (data on 10.1.06) was mainly due to control of the susceptible biotype, with the resistant survivors (identified by their morphological traits) subsequently dominating the plots, leading to low percent control figures at the assessment on 20.2.06. Fortunately, all the post-emergence herbicides, with the exception of flumetsulam, provided good control of the resistant biotype as well as the susceptible biotype in Trial 2 .

TABLE 1: Control of fathen (\% plants damaged/killed relative to untreated) from various herbicide treatments applied to Trial 1 on 8 December 2005 and to Trial 2 on 24 December 2005.

\begin{tabular}{lcccccc}
\hline & Rate & \multicolumn{2}{c}{ Trial 1 } & & \multicolumn{2}{c}{ Trial 2 } \\
\cline { 3 - 4 } \cline { 6 - 7 } Treatment & $(\mathrm{g}$ ai/ha $)$ & 11.1 .06 & 20.2 .06 & & 10.1 .06 & 20.2 .06 \\
\hline Untreated & - & 0 & 0 & & 0 & 0 \\
pyridate & 450 & 100 & 100 & & 99 & 100 \\
bromoxynil & 450 & 100 & 100 & & 100 & 100 \\
nicosulfuron & 60 & 92 & 100 & & 91 & 100 \\
mesotrione & 96 & 100 & 100 & & 99 & 100 \\
flumetsulam & 40 & 71 & 63 & & 83 & 66 \\
dicamba & 300 & 96 & 98 & & 71 & 0 \\
dicamba & 600 & 100 & 100 & & 78 & 32 \\
dicamba & 1200 & 100 & 100 & & 78 & 0 \\
dicamba & 2400 & 100 & 100 & & 80 & 13 \\
LSD $(\mathrm{P}<0.05)$ & & 5.3 & 5.7 & & 25.8 & 18.6 \\
\hline
\end{tabular}

Results from Trial 3 (carried out the following year on the site of Trial 2) showed that all post-emergence herbicides, including flumetsulam but with the exception of dicamba, gave excellent control of fathen and this control lasted well into the growing season (Table 2). Nicosulfuron and flumetsulam were slower acting initially, but showed efficacy similar to other treatments 4 weeks after treatment. A visual differentiation of the fathen population in untreated plots showed that on average $70 \%$ of plants were the dicamba resistant biotype. Thus control levels of 35-60\% for the dicamba treatments (Table 2) were most likely achieved by killing the susceptible biotype only. The number of fathen plants in the dicamba treated plots was not significantly different from untreated plots (Table 3), suggesting that the majority of plants were the dicamba resistant biotype. Visual observations of morphological characteristics of plants also confirmed this.

Weeds other than fathen present in Trial 3 were mainly black nightshade (Solanum nigrum), willow weed (Persicaria persicaria), redroot (Amaranthus powellii), seedling broad-leaved dock (Rumex obtusifolius) and smooth witchgrass (Panicum dichotomiflorum), with small amounts of twin cress (Coronopus didymus) and hedge mustard (Sisymbrium officinale). Nicosulfuron and mesotrione showed much better overall efficacy than pyridate, bromoxynil or flumetsulam on other weeds (Table 2). Dicamba at all rates also showed good efficacy on most weeds present, other than fathen. Smooth witchgrass probably did not have an opportunity to establish well in the dicamba plots due to the ground cover of fathen except at the highest rate where maize grew poorly. Plant density of broadleaf weeds other than fathen and the grass weeds (Table 3) confirm the excellent efficacy of nicosulfuron applied post-emergence to grasses, as observed in previous trials (James et al. 2006). Dry matter weights of the three weed categories (Table 3 ) support the trends shown by plant density and had less variability between plots than the plant counts. The high dry matter yields of fathen and grass weeds in the dicamba plots, especially those treated with the highest rate, were due to severe damage to the maize crop and the resultant lack of canopy closure. This damage was 
reflected in the maize grain yield with a trend for decreasing yield with increasing rate of dicamba (Table 3). All post-emergence treatments other than the two high rates of dicamba resulted in yields significantly higher than the untreated plots.

TABLE 2: Control of fathen and other weeds (\% plants damaged/killed relative to untreated) present in Trial 3 after application of herbicides on 12 December 2006.

\begin{tabular}{|c|c|c|c|c|c|c|c|}
\hline \multirow[b]{2}{*}{ Treatment } & \multirow{2}{*}{$\begin{array}{c}\text { Rate } \\
\text { g ai/ha }\end{array}$} & \multicolumn{3}{|c|}{ Fathen } & \multicolumn{3}{|c|}{ Other weeds } \\
\hline & & 19.12 .06 & 11.1 .07 & 14.2 .07 & 19.12 .06 & 11.1 .07 & 14.2.07 \\
\hline Untreated & - & 0 & 0 & 0 & 0 & 0 & 0 \\
\hline pyridate & 450 & 98 & 95 & 100 & 75 & 55 & 58 \\
\hline bromoxynil & 450 & 99 & 97 & 99 & 76 & 63 & 58 \\
\hline nicosulfuron & 60 & 68 & 99 & 100 & 66 & 95 & 96 \\
\hline mesotrione & 96 & 98 & 98 & 100 & 93 & 93 & 92 \\
\hline flumetsulam & 40 & 61 & 95 & 93 & 61 & 65 & 69 \\
\hline dicamba & 300 & 49 & 30 & 35 & 68 & 85 & 86 \\
\hline dicamba & 600 & 48 & 30 & 45 & 63 & 85 & 85 \\
\hline dicamba & 1200 & 58 & 50 & 50 & 71 & 84 & 85 \\
\hline dicamba & 2400 & 61 & 60 & 53 & 75 & 89 & 76 \\
\hline $\begin{array}{l}\text { LSD } \\
(\mathrm{P}<0.05)\end{array}$ & & 7.9 & 9.8 & 13.7 & 7.9 & 13.3 & 10.3 \\
\hline
\end{tabular}

TABLE 3: Plant numbers and dry weights of fathen, other broadleaf and grass weeds determined on 14.2.07, and maize grain yield on 1.5.07 in Trial 3.

\begin{tabular}{|c|c|c|c|c|c|c|c|c|}
\hline \multirow[b]{2}{*}{ Treatment } & \multirow[b]{2}{*}{$\begin{array}{c}\text { Rate } \\
\text { (g ai/ha) }\end{array}$} & \multicolumn{3}{|c|}{ Plants $/ \mathrm{m}^{2}$} & \multicolumn{3}{|c|}{$\mathrm{DM}(\mathrm{kg} / \mathrm{ha})^{1}$} & \multirow{2}{*}{$\begin{array}{l}\text { Grain } \\
\text { yield } \\
\text { (t/ha) }\end{array}$} \\
\hline & & Fathen & $\begin{array}{l}\text { Other } \\
\text { weeds }\end{array}$ & $\begin{array}{c}\text { Grass } \\
\text { weeds }\end{array}$ & Fathen & $\begin{array}{l}\text { Other } \\
\text { weeds }\end{array}$ & $\begin{array}{c}\text { Grass } \\
\text { weeds }\end{array}$ & \\
\hline Untreated & - & 95 & 95 & 23 & $3370 \mathrm{a}$ & $3280 \mathrm{a}$ & $14 \mathrm{c}$ & 8.6 \\
\hline pyridate & 450 & 5 & 70 & 53 & $49 \mathrm{~b}$ & $2350 \mathrm{ab}$ & $200 \mathrm{~b}$ & 10.3 \\
\hline bromoxynil & 450 & 8 & 73 & 83 & $15 \mathrm{~b}$ & $1340 \mathrm{ab}$ & $430 \mathrm{a}$ & 10.6 \\
\hline nicosulfuron & 60 & 9 & 54 & 3 & $59 \mathrm{~b}$ & $1200 \mathrm{~b}$ & $4 \mathrm{c}$ & 11.3 \\
\hline mesotrione & 96 & 3 & 16 & 83 & $17 \mathrm{~b}$ & $67 \mathrm{c}$ & $1050 \mathrm{a}$ & 10.9 \\
\hline flumetsulam & 40 & 18 & 55 & 48 & $135 \mathrm{~b}$ & $1170 \mathrm{~b}$ & $410 \mathrm{ab}$ & 10.4 \\
\hline dicamba & 300 & 103 & 3 & 58 & $2440 \mathrm{a}$ & $8 \mathrm{~d}$ & $660 \mathrm{a}$ & 10.6 \\
\hline dicamba & 600 & 100 & 3 & 88 & $1600 \mathrm{a}$ & $0 \mathrm{~d}$ & $430 \mathrm{a}$ & 10.0 \\
\hline dicamba & 1200 & 93 & 3 & 55 & $1480 \mathrm{a}$ & $0 \mathrm{~d}$ & $630 \mathrm{a}$ & 9.3 \\
\hline dicamba & 2400 & 70 & 0 & 63 & $2170 \mathrm{a}$ & $0 \mathrm{~d}$ & $1490 \mathrm{a}$ & 7.6 \\
\hline $\begin{array}{l}\text { LSD } \\
(\mathrm{P}<0.05)\end{array}$ & & 33.1 & 22.5 & 53.9 & & & & 1.1 \\
\hline
\end{tabular}

${ }^{1}$ Means with the same letter within the column are not significantly different from each other $(\mathrm{P}<0.05)$. 
Soil samples collected from Trial 3 before planting of the maize crop had an average of $1813 / \mathrm{m}^{2}$ (range $1120-4074$ ) of viable fathen seeds. Soil samples collected after crop harvest from the untreated plots had an average of 1794 viable seeds $/ \mathrm{m}^{2}$. As a comparison, the mesotrione treatment, which provided good overall weed control, had only 338 viable seeds $/ \mathrm{m}^{2}$. The four dicamba treatments had an average of 2510,1100 , 680 and 800 viable seeds $/ \mathrm{m}^{2}$, respectively, showing a decreasing trend with increasing rate, although only the lowest rate was significantly different from the other three rates. Data obtained through the seedling germination method supported this trend, although the numbers for seedlings were up to 2 times more than the seed counts, presumably because of the larger volume of soil used in the glasshouse (Rahman et al. 2001a). These limited data suggest that in untreated plots the number of fathen seed in the soil seedbank at the end of the growing season remained similar to those recorded in spring, but dropped considerably in plots where good control of fathen was achieved during the season. This provides some hope for significantly reducing the weed seedbank in the long term when fathen plants are controlled effectively.

Results from these trials have confirmed the presence of a fathen biotype resistant to dicamba in some maize fields. Fortunately a number of post-emergence herbicide options currently available to maize growers are as effective for the control of this biotype, as they are for the susceptible biotype. Although the extra spraying operation would inevitably add to the cost of growing the maize crop, it is important to apply an effective post-emergence treatment to control and restrict the build-up of this resistant biotype in New Zealand.

\section{ACKNOWLEGEMENTS}

We thank the growers Ian Franich and Murray Hart for providing and maintaining the trial sites. Financial support for this work was provided by the New Zealand Foundation for Research, Science and Technology and the Foundation for Arable Research.

\section{REFERENCES}

James TK, Rahman A, Trolove M 2006. Optimal timing for post-emergence applications of nicosulfuron for weed control in maize. New Zealand Plant Protection 59: 250-254.

James TK, Rahman A, Mellsop JM 2005. Fathen (Chenopodium album): A biotype resistant to dicamba. New Zealand Plant Protection 58: 152-156.

Rahman A. 1982. Resistance of weeds to herbicides in New Zealand. In: Geelen JA, Esson MJ ed. Pesticide Resistance Seminar. Hawke's Bay Branch of New Zealand Weed and Pest Control Society, Hastings, New Zealand. Pp. 13-36.

Rahman A, James TK, Grbavac N 2001a. Potential of weed seedbanks for managing weeds. A Review of Recent New Zealand Research. Weed Biology and Management 1: 89-95.

Rahman A, James TK, Seefeldt S 2001b. The current situation with herbicide resistant weeds in New Zealand. Proceedings of the $18^{\text {th }}$ Asian-Pacific Weed Science Society Conference. Pp. 500-508.

Rahman A, James TK, Mortimer J 1983. Control of atrazine resistant fathen in maize. Proceedings of the 36th New Zealand Weed and Pest Control Conference. Pp. 229-232. 